\title{
Raúl Prebisch: \\ his years in government
}

Roberto Cortés Conde*

\section{The early years}

The Prebisch that most people remember nowadays was a distinguished figure in international circles, with only sporadic interventions (1955 and 1984) in the economic affairs of Argentina, but this Prebisch who lived outside Argentina in the second half of the twentieth century played an extremely important role when he was a young man in the design and implementation of policies that brought about notable changes in that country.

He had graduated from the Faculty of Economic Sciences in 1923, and twenty years later, when he was still only 42 years old, he was forced to put an end to his work as General Manager of the Central Bank of the Argentine Republic, after eight years in that post and after having occupied high posts in the government.

When he was still a student he translated the study that J.H. Williams presented at the seminars of the school. ${ }^{1}$ That work, and through it Taussig's ideas on economic cycles and balance of payments adjustments with capital movements, gave him the idea of analysing the Argentine cycles and mechanisms not envisaged in current international trade theory.

\footnotetext{
* Department of Economics of the University of San Andrés, Buenos Aires (cortes@udesa.edu.ar). This is an edited version of the presentation that the author made at ECLAC headquarters in Santiago, Chile, on 17 April 2001, on the occasion of the hundredth anniversary of Raul Prebisch's birth.

${ }^{1}$ See Williams, 1969.
}

In 1922 Alejandro Bunge put forward his name to occupy the post of Director of Statistics of the Sociedad Rural Argentina. There he headed a team which in 1928 published a yearbook with the fullest historicostatistical information on the country to date.

In that same year he was entrusted with the organization of an economic research department in the Banco de la Nación Argentina, where he was to carry out important work on the compilation of statistics and short-term economic analysis, published in the Bank's Revista económica (BNA, 1928).

When Argentina was faced with new problems in the 1930s, the theoretical and statistical knowledge thus acquired allowed him to meet a challenge to which few intellectuals of that country have been able to respond. The circumstances he had to live in: the end of one world, that of the belle époque, and the appearance of a new one, that of closed economies and nationalist reactions, were hard for anyone to understand.

It was necessary to adapt or construct theories to explain phenomena which were previously unknown and hence had never been studied before. His visit to Australia in the 1920s and his stay in the United States -including his friendship with Williams- helped him in this task and allowed him to keep abreast of the newest intellectual developments.

Under the influence of Williams' study on balance of payments adjustment mechanisms in a country with inconvertible paper money and the theories on economic cycles (Taussig, 1915; Hawtrey, 1919; 
Kondratieff, 1946), he began to work out new interpretations on the characteristics of the Argentine cycle. Argentina had an economy which depended on its exports of cereals, and this gave it a seasonal nature and also made it very vulnerable, since it was affected both by weather conditions and by the big fluctuations in international markets. There was also a monetary system which further accentuated such fluctuations. The seasonal cycle -which had come to be called the Argentine cycle- meant that when the harvests were sold in the summer months there was an inflow of gold and the banks expanded their supply of credit, whereas in winter, when there were no export proceeds, there was a shrinkage in national income and the banks reduced their credit. This gave rise to the idea of taking counter-cyclical measures.

In 1921, while he was still a student in the school of Economic Sciences, Prebisch published his "Notas para la historia monetaria de la Argentina" (Prebisch, 1921), in which he went back all the way to colonial monetary antecedents, noting that it was paradoxical that in a colony producing silver there was a shortage of currency. It was not that there was a shortage of silver, he said, but that as the Mint received currency at a lower price than it had as a commodity, it hoarded it and only circulated bad money: the "macuquina", a feeble currency which was considered to be of little value because of its low content of silver, or local substitutes. In his "Notas" he studied the experience of issuing banks and inconvertible paper currency, as well as the crises of 1876, 1885 and 1890 , maintaining that they were the result of over-expansion of credit in the upward phases of the cycle, in which purchasing power was created through money issue, whereas this situation was reversed when a deficit appeared in the balance of payments and the money supply had to be reduced. In the last part of the article in question he dealt with the 1913 crisis and began to outline a theory on monetary disturbances in the phases of cycles with a Currency Board system: a theory which he later developed in the Central Bank, in that institution's Memoria for 1938 (BCRA, 1939). He said in that respect that whereas in issuing banks the money issue is based on commercial credit, in a Currency Board system money can only be issued on the basis of the balance of payments surplus (gold reserves). He noted however that even under the latter system inflows of gold produce not only an increase in the money supply but also an increase in the reserves of the banks, which, because they have more reserves, likewise expand credit. Hence, in an upward phase of the cycle there is over-expansion of credit (a procyclical tendency), whereas when the opposite takes place there is an outflow of gold, the reserves go down, and credit shrinks still further. This is what happened in the upward phase of the cycle in 1913, he said, causing a chain reaction and giving rise to generalized pessimism on the economic outlook which made the recession still worse through its effects on consumption and investment.

\section{His years in government and in the Central Bank}

The 1930s was a period of enormous difficulties, but also of new experiences in the formulation and implementation of economic policies, under the new roles taken on by the government.

The 1930 world crisis made it necessary for Argentina to place itself in a totally different international context and find answers to situations which were previously unknown.

In 1933 Prebisch had read the four articles by Keynes published in The Times, after which, he said, "I began to think about an expansionary policy". ${ }^{2}$ Later on, he was to play a leading part in disseminating Keynes's ideas in Spanish (Prebisch, 1947).

After the enormous upsets in the international goods and capital markets during the period following the First World War, the rigidity of the Gold Standard had become obvious. Argentina had been one of the few countries which, following the lead of Great Britain, had returned to a Currency Board system in 1927, at the parity which had prevailed before the war. It may be noted that during the time that that system had been closed down, currency issue had continued under the rules of the Gold Standard. In 1914 a law had been adopted permitting the issue of money on the basis of the discounting of paper of the Banco de la Nación Argentina, provided that $40 \%$ of the reserves were kept in gold. This law had not been used, however. In 1929, after the collapse of the New York Stock Exchange, and fearing a run on the banks, the government decided to close down the Currency Board, but it did not prevent remittances abroad and, after the first devaluation, it tried to maintain an overvalued exchange rate for the peso by selling gold. After the 1930 revolution, and finding itself in a difficult situation because the outflow of gold to pay debts and imports continued and delays were building up in the delivery of foreign exchange, it decided -in line with the 1914 law- that the Currency Board would issue money on the basis of paper

\footnotetext{
${ }^{2}$ Quoted in Fernández López, 1996.
} 
discounted by the Banco de la Nación Argentina. As Prebisch (who had been Under-Secretary of Finance up to 1932) noted, that measure did not yet represent a change from the orthodox policy with which the government aimed to face the crisis (i.e., reducing expenditure and increasing taxes), but was taken because it was urgently necessary to replenish the assets of the banking system, which had been exhausted with the outflow of gold. At all events, however, the Gold Standard system was made more flexible. Taxes were established on remittances and government expenditure was reduced by lowering the wages of public employees. Rather than because of the closing down of the Currency Board and the application of the 1914 law, 1932 was important because it was then that money was issued on the basis of public securities in order to finance the Treasury deficit and a new conception of the monetary system came into being.

In 1933, with the entry of Pinedo into the Cabinet as Minister of Finance and the return of Prebisch as Under-Secretary, measures were applied which formed part of a plan guided by a new conception of economic policy. At the request of ministers Pinedo and Duhau, certain economic measures were formulated which were reflected in the National Economic Plan of Action of November 1933.

In that year the peso was devalued, not only in order to balance the balance of payments but also in order to support the agricultural sector. There was, said Prebisch, a true redistribution of profits; it was not just a mere exchange rate measure but was combined with the purchase of the harvest surpluses which it had not been possible to sell, in order to give the population greater purchasing power. It also aimed to stimulate economic activity through public works programmes and aid for industry.

Exchange controls were also established, with two markets: one official, on which the foreign exchange corresponding to the official prices of regular exports was sold, and the other a free market on which the excess over the official prices and the income from non-traditional exports to neighbouring countries could be changed. Two exchange rates were established: a buying rate at 15 pesos per pound sterling, and a selling rate which was finally set at 17 pesos. Since at these rates the demand for foreign exchange was greater than the supply, foreign exchange was rationed through prior import licences granted according to criteria fixed by the government. As Prebisch said: "Now, for the first time, we are putting into effect a monetary and financial plan which is above the old traditional influences" (BCRA, 1986, p. 50).
It was the understanding of everyone that these measures were of an extraordinary nature, as were the situations they sought to correct, and that when the Central Bank was set up in 1935 and exchange controls were allowed to continue, there was nevertheless the intention of getting rid of the latter and returning to a free market. In the message accompanying the bill proposing the establishment of the Central Bank noted Prebisch-it was clearly stated that the aim was to establish a bank which would maintain the stability of the currency and make it possible to return to normal in monetary matters, but only provided that the main nations of the world did the same and that international trade was restored. But "if a system of closed economies prevails" -added the message- "the country will have, in its Central Bank, the means for adapting its policies to this de facto situation, in defence of the national interests" (BCRA, 1986, p. 51). These measures were adopted, then, in response to the closure of the economies of the most highly developed countries.

\section{The Central Bank}

Prebisch was a member of the first commission responsible for drafting a project for a central bank, but this was rejected in favour of a project by Otto Niemeyer, who had already prepared a similar project for Brazil. The 1935 law, however, differed from the Niemeyer project and incorporated modifications which bore the stamp of Prebisch.

The creation of the Central Bank was designed to achieve monetary stability and reduce the disturbances of the economic cycle. Prebisch maintained that in view of the characteristics of the cycle in Argentina, the Central Bank should intervene to smooth out the fluctuations by using absorption instruments. He considered that rediscounting, in contrast, would play only a transitory role.

"Thus, although the Bank was along classical lines ... the actual situation would not allow it to act in that manner" and "the possibility of applying another type of policy" should be envisaged. Here, he reiterated the concepts which he had already put forward in the early 1930s in "La acción de emergencia en el problema monetario" (Prebisch, 1991, p. 51). He went on to say "The strict Gold Standard system had an intrinsic flaw: during the upward phase the banks' assets grow, and this leads them to lend more money, because of the natural competition among them, so that they create more purchasing power than would be warranted by 
the balance of payments position. This creation of purchasing power expands the effects of the upward phase but makes necessary a more violent contraction in the downward phase. But this is not the case if, instead of creating money, the compulsory reserves of the banks are increased during the upward phase, this extra cash is collected and sterilized so that it cannot serve to expand credit, and it is then returned when the situation is reversed, in order to avoid a contraction" (Ibid., p. 52).

Rediscounting would be used only in limited cases: when a harvest failed or exports went down and there was an outflow of hard money. In those circumstances, rediscounting was in order in order to take pressure off the economy and prevent a contraction in agricultural activity and all the other activities connected with it.

The first intervention by the Central Bank took place from 1935 to mid-1937, in the upward phase, and involved the creation of absorption certificates which made it possible to sterilize purchasing power (saving), as well as buying back part of the external debt in dollars. When it was observed, in mid-1937, that the cycle was turning round and a downward phase was beginning, the reserves were used to give back purchasing power to the public in order to prevent a recession from spreading. The idea was to soften the cyclic curve and this, said Prebisch, was the second stage in "our monetary ideas". Up to then, purchasing power was taken away in the upward phase and returned in the downward phase, but money was not created.

In the next intervention, during the early years of the Second World War, the authorities went much further. In view of the severe contraction in the early years of the war, when traditional markets disappeared, it was decided to try to give a more active role to the policy of regulating the means of payment, by creating purchasing power in order to promote industry and construction work; that is to say, it was decided to apply very active market policies in order to promote the development of the economy, but within a monetary circuit controlled through the exchange control system.

This idea had been at the centre of the proposal made by minister Pinedo in his 1940 economic reactivation plan (BCRA,1986), which consisted of mobilizing the enormous amount of idle deposits invested in the short term in the financial system, so that through the intervention of the Central Bank -which would purchase those deposits- the commercial banks would be able to make long-term loans, primarily for promoting construction (which was the most dynamic engine of growth in Prebisch's view) and local industry. This would have to be done with extreme caution, and only as long as there was not full employment of the factors of production, because otherwise it would lead to inflation.

These measures -said Prebisch-finally turned out to be unnecessary, because from 1941 on, with the entry of the United States into the war, exports increased, the supply of imports was reduced, and purchasing power rose within the country. This instrument was, however, to be used later in very different circumstances with highly inflationary consequences, which he criticized in his 1955 report to the Argentine government (BCRA, 1956).

\section{Conclusions}

In his years in government, Prebisch played a leading part in the formulation of new ideas and economic policies which had a profound influence in following decades. Many of them were put forward in response to exceptional circumstances, and were to be abandoned if those circumstances disappeared. In the final analysis, they were responses to a world in which economies had closed and there were no international capital markets.

The starting point for these ideas was the conviction that the Gold Standard could avoid monetary crises, but not banking crises, which had serious consequences for the whole economy because of the pro-cyclical nature of bank credit. Prebisch proposed that compulsory reserves should be increased in the expansion phase and reduced in the contraction phase, and that a reserve fund should be established which would withdraw purchasing power from the public (through absorption certificates) and return it to them (by buying back those certificates) in the downward phase, while rediscounting should be only a transitory measure. In order for that purchasing power not to be diverted towards imports, there should be an exchange control system with selective exchange permits.

Although Prebisch does not actually say this in as many words, the idea was that counter-cyclical policies should be applied in the upward phase, when it is possible to build up reserves, for if it is not possible to restore purchasing power in the downward phase, this can only be expanded by creating money, which he does not recommend as it would produce inflation. All this, however -and this is an aspect which Prebisch does not mention because it seems so obvious- requires a thoroughly solvent and credible State. 
In reality, this is rather similar to smoothing of taxes. But why use a monetary instrument instead of a fiscal one, then? In fact, fiscal instruments were not ruled out, since in the upward phase in 1935-1937 external debt was bought back with part of the surplus, but apparently it was politically easier to restrict credit by increasing the reserves in an upward phase than to increase taxes or reduce expenditure, when this had already been done earlier in order to balance the budget.

Finally, the last stage in what Prebisch called his thinking on economic management has to do with the reactivation plan prepared by minister Pinedo and the Central Bank policies designed to use the surplus of short-term deposits for long-term loans in order to promote construction and industrial activity. The Central Bank was to take those short-term deposits and then lend them to the banks on a long-term basis, the justification for that measure being the upsets caused by the war in agricultural production, which had no outlet for its goods, and the need to orient activities toward the domestic market. The entry of the United States into the conflict in 1941 changed the situation, however, as exports of wool and hides to that country increased, while imports went down, thus balancing the balance of payments and, in Prebisch's view, making it unnecessary to apply the measure.

At all events, however, new policy instruments had now been created.

After Prebisch had been removed from the Central Bank, in 1943, that institution made repeated widespread use of rediscounting, with very adverse consequences for the economy, as he himself emphasized in his 1955 report to the Argentine government (BCRA,1956). By then, after more than a decade in the government, his economic ideas had reached maturity, and since that time they have had an undeniable influence on numerous aspects of the economic thinking and history of Argentina.

(Original: Spanish)

\section{Bibliography}

BCRA (Banco Central de la República Argentina) (1939): Memoria anual del Banco Central, 1938, Buenos Aires. (1956): Memoria anual del Banco Central, 1955, apéndice I, Buenos Aires.

(1986): 1935-1985: Cincuentenario del Banco Central de la República Argentina, Buenos Aires.

BNA (Banco de la Nación Argentina) (1928): Revista económica, Buenos Aires.

Fernández López, M. (1996): El ciclo económico argentino: estudios de Raúl Prebisch, Revista ciclos, vol. VI, No. 10, Buenos Aires, Universidad de Buenos Aires.

Hawtrey, R.G. (1919): Currency and Credit, London.
Kondratieff, N.I. (1946): Las ondas largas de la economía, Madrid. Prebisch, R. (1921): Notas para la historia monetaria de la Argentina, Revista de ciencias económicas, Buenos Aires.

(1947): Introducción a Keynes, Mexico City, Fondo de Cultura Económica.

(1991): La acción de emergencia en el problema monetario, in Raúl Prebisch. Obras 1919-1948, vol. II, Buenos Aires, Fundación Raúl Prebisch.

Taussig, F.W. (1915): Principles of Economics, New York, The Macmillan Company.

Williams, J.H. (1969): Argentine International Trade Under Inconvertible Paper Money, 1880-1900, New York, Greenwood Press. 